\title{
MINERAL AND ENERGY RESOURCE ASSESSMENT MAPS OF THE MOUNT KATMAI, NAKNEK, AND WESTERN AFOGNAK QUADRANGLES, ALASKA
}

By

\author{
S.E. Church, J.R. Riehle, L.B. Magoon, and D.L. Campbell
}

\section{SUMMARY OF MINERAL AND ENERGY RESOURCES}

On the basis of new geologic mapping and exploration geochemical studies, we have provided a mineral and energy resource assessment of the Mount Katmai, Naknek, and western Afognak quadrangles, Alaska. We delineate four tracts of ground that have metallic mineral resources. The mineral deposit types considered in each tract are summarized in table 4. Estimates of the number of undiscovered mineral deposits have been made for porphyry copper and polymetallic vein deposits. We estimate that one undiscovered porphyry copper deposit is present in the Katmai study area at the ten percent probability level. Although the sampling density may be too low to give an accurate estimate of the number of undiscovered polymetallic vein deposits, we suggest that, at a minimum, there is a five percent probability for five or more undiscovered polymetallic vein deposits in the Katmai study area. In addition, several areas have potential for undiscovered porphyry molybdenum, massive sulfide, and epithermal gold and mercury deposits.

Several placer gold claims have been filed in the area; one is still active. One claim, on American Creek, produced a small but unknown amount of gold. Several source areas for gold are identified in this study and would provide potential sources for gold in stream placer deposits given the right hydrologic conditions. Many of these sites in the Kulik Lake area have been prospected with only limited success. However, the upper reaches of Ikagluik Creek and some areas of the Rainbow River in the central part of Katmai National Park may also contain undiscovered placer gold resources. Berryhill (1963) investigated the titanium-rich black sand beach placers along the coast of Bristol Bay at Egegik Bay and concluded that they did not constitute a resource for either titanium or gold.

Sand and gravel deposits are locally abundant (Riehle and Detterman, in press) and are adequate to supply local demand. No cinder resources have been delineated.

Energy potential evaluated during the study includes geothermal, oil and gas, and coal resources. A few warm springs were found, but no hot springs areas suitable for geothermal 
development exist within the study area. Better sites for geothermal resources have been identified on the Alaska Peninsula south of the study area (Smith and Shaw, 1975).

The potential for commercial accumulations of oil and gas in the Naknek, Mount Katmai, and western Afognak quadrangles is low. Area E1, in the Naknek quadrangle along Bristol Bay, has low potential for thermogenic oil and gas (Church, Detterman, and Wilson, 1989). In area E2, oil seeps are along the anticlinal structures both north and south of the Katmai study area. Studies by Magoon and Anders (1992) indicate that the oil is from lower Mesozoic sedimentary rocks. Surface exposures of the Naknek Formation have uniformly indicated poor reservoir characteristics where studied, both here and in the adjacent quadrangles, and the shallow depth of burial of the Naknek Formation probably would result in flushing of the reservoir by meteoric water if oil were present.

Coal seams as much as several meters in aggregate thickness crop out in Tertiary rocks in the Geographic Harbor area. Since these coal beds occur within withdrawn Federal lands, there has been no incentive to evaluate them as coal resources. Given different land accessibility and a local market, these beds could constitute a small marketable coal resource.

\section{INTRODUCTION}

The U.S. Geological Survey is required by the Alaska National Interest Lands Conservation Act (ANILCA, Public Law 96-487) to survey Federal lands in Alaska to determine their resource endowment. As a part of the Alaska Mineral Resource Assessment Program (AMRAP), a study of the geology and geochemistry of the Mount Katmai quadrangle and adjoining parts of the Naknek and western Afognak quadrangles was undertaken during the summer field seasons in 1983-87. In this report, we refer to this area as the Katmai study area or simply the study area. This report presents a summary of the mineral and energy resources of the study area.

\section{Land Status}

Much of the acreage in the study area, particularly along the Aleutian Range, is in the Katmai National Park and Preserve and Becharof National Wildlife Refuge. The U.S. Bureau of Land Management has land holdings in the northwestern part of the Naknek quadrangle. The McNeil River State Game Sanctuary extends into the northern part of the Mount Katmai quadrangle in one township (T. 14 S., R. 32 W.) along the upper reaches of the McNeil and Little Kamishik Rivers. The state of Alaska has land holdings on the upper reaches of the Naknek River, the King Salmon River, and the Egegik River to protect the salmon habitat. The
Bristol Bay Native Corporation and private land owners hold much of the land along the lower course of the Naknek River between the towns of Naknek and King Salmon (U.S. Bureau of Land Management, 1987).

\section{REGIONAL GEOLOGY}

The Alaska Peninsula is a convergent plate margin that has been episodically active since Jurassic time. A Tertiary island arc assemblage of volcanic rocks have intruded earlier Mesozoic continental and marine rocks. The Alaska Peninsula is on continental crust, the boundary between continental and oceanic crust is near Unimak Island (Scholl and others, 1975; D.W. Scholl, written commun., 1989), about $600 \mathrm{~km}$ southwest of the Katmai study area. A generalized geologic map of the Alaska Peninsula is shown in figure 1. In this section, we briefly describe the geology of the Katmai study area in a regional context as it relates to the mineral and energy resource appraisal. A more detailed discussion of the individual rock units present in the Katmai study area is given in the resource assessment section. We discuss the mineral resources in terms of the geologic environment starting with the oldest rocks that are found in the study area. The geologic mapping of Riehle and others (in press) is used as the base for the mineral resource assessment. A more detailed geologic discussion of the Katmai study area is given in Church and others (in press). Regional stratigraphic 
relationships and correlations among map units are based in part on Detterman and others (in press).

The oldest rock on the Alaska Peninsula is Permian marine limestone exposed just south of the Katmai study area in the Karluk quadrangle (Hanson, 1957). In the Katmai and Iliamna quadrangles, the oldest rocks are Triassic submarine basalt flows and marine limestone (Detterman and Reed, 1980). Detterman and others (in press) have revised their earlier work which suggested that Paleozoic limestone was present in the Gertrude Creek area (Detterman and others, 1979). The Triassic rocks are followed in stratigraphic succession by Lower Jurassic lava flows, breccias, and associated marine sedimentary rocks of a volcanic arc (Detterman and Hartsock, 1966; Reed and Lanphere, 1973) and by Middle Jurassic, marine sedimentary rocks (Detterman and others, in press).

Intrusion of the Alaska-Aleutian Range batholith during Middle Jurassic time metamorphosed Middle Jurassic and older rocks. These metamorphic rocks are present as roof pendants in the Alaska-Aleutian Range batholith, which extends from the central Alaska Peninsula northward for $750 \mathrm{~km}$ (Reed and Lanphere, 1969, 1973). Middle to Upper Jurassic, marine sedimentary strata were deposited during uplift and erosion of the batholith and its cover of older sedimentary and volcanic rocks (Egbert and Magoon, 1981). Although Cretaceous sedimentary rocks, both nonmarine and marine, are found discontinuously along the length of the Alaska Peninsula (Detterman and others, in press), mid-Cretaceous rocks are absent in the southern part of the Katmai study area because of widespread uplift and erosion (Fisher and others, 1981). Locally, Albian rocks crop out at the north and south(?) ends of the Alaska Peninsula (Petering and Smith, 1981; Detterman and others, in press).

Cretaceous and Tertiary sedimentary rocks are thin or absent across the Alaska Peninsula near Becharof Lake (fig. 1), indicating the presence of a structural high (Fisher and others, 1981). Lower Tertiary strata appear to pinch out on the south flank of the high (Detterman and others, 1987), implying that the high existed by early Tertiary time. Tertiary strata are in excess of $5,000 \mathrm{~m}$ thick at both the south end of the Alaska Peninsula (Detterman and others, in press) and to the north in the Cook Inlet region (Calderwood and Fackler, 1972). Tertiary rocks south of the Becharof Lake structural high are composed of mixed marine and continental sedimentary deposits whereas those to the north are exclusively continental in origin (Magoon and Egbert, 1986; Detterman and others, in press).

Widespread, early Tertiary volcanism on the Alaska Peninsula south of Becharof Lake (Wilson, 1985) and in the Aleutian Islands (Scholl and others, 1975) documents the start of the Aleutian volcanic arc in its present tectonic setting (Wallace and Engebretsen, 1984). Early Tertiary volcanic rocks also have been mapped north of Naknek Lake in the study area (Riehle and others, in press) and these rocks continue north into the Iliamna quadrangle (Detterman and Reed, 1980). Tertiary plutonic rocks in the Katmai study area (Riehle and others, in press) and in the Iliamna quadrangle (Detterman and Reed, 1980) may be deep-seated equivalents of some of the nearby volcanic rocks. After a brief quiescence, magmatism throughout the Aleutian arc began again in the Miocene and has continued to the present (Marlow and others, 1973; Wilson, 1981). The locus of late Tertiary magmatism closely overlaps that of early Tertiary magmatism in the insular part of the arc (Scholl and others, 1975) and it approximately overlaps the Alaska Peninsula as far south as about $57^{\circ}$ latitude (Wilson, 1985). In the Katmai region, however, early and late Tertiary volcanic rocks are widely separated on opposite sides of the Bruin Bay fault (Riehle and others, in press).

Two main periods of deformation on the Alaska Peninsula can be demonstrated, one in the Middle Jurassic and a second in the late Tertiary. Metamorphic rocks northwest of the Bruin Bay fault in the Katmai study area (Riehle and others, in press) and in the Iliamna quadrangle to the north (Detterman and Reed, 1980) were folded during intrusion of adjacent Jurassic plutons. Fold axes trend northeast. The paucity of mid-Cretaceous rocks on the Alaska Peninsula (Detterman and others, in press; Wilson and others, 1981) is interpreted to indicate widespread erosion of older rocks prior to deposition of strata of Late Cretaceous age. Regional folding about northeast-trending axes occurred again in the Tertiary. At the south end of the Alaska Peninsula, rocks as young as Oligocene are tightly folded whereas adjacent Miocene rocks are nearly flat-lying (F.H. Wilson, written commun., 1988). In the Katmai study area southwest of the Bruin Bay fault, rocks as young as Miocene are gently folded (Riehle and others, in press).

The Bruin Bay fault (fig. 1), which is the most prominent structure of the Alaska Peninsula, extends from upper Cook Inlet, about $400 \mathrm{~km}$ north of the Katmai study area, to just south of Becharof Lake where it is covered beneath thick surficial deposits 


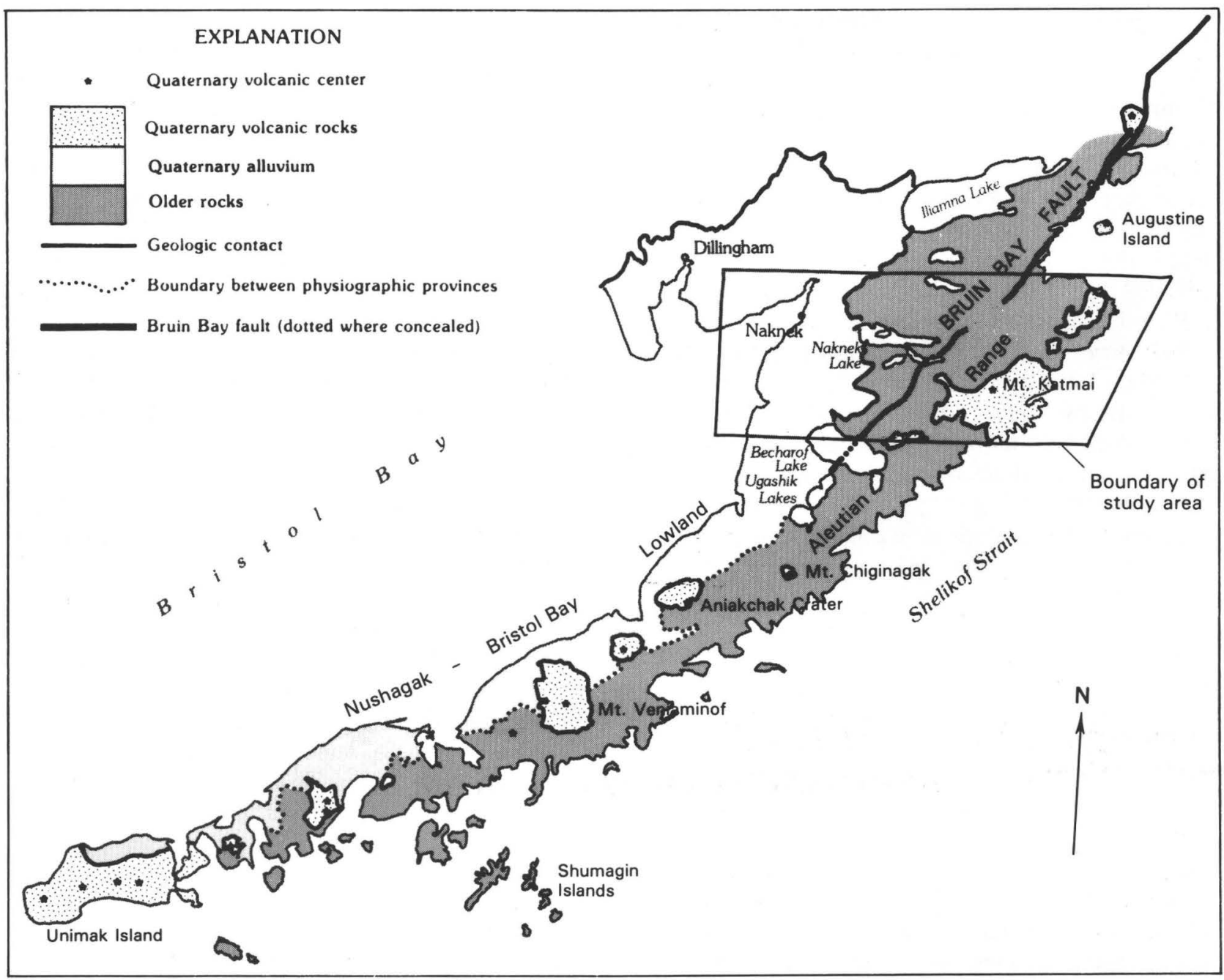

Figure 1. Index map of the Alaska Peninsula showing the location of the Katmai study area, which encompasses the Mount Katmai, Naknek, and western Afognak quadrangles, Alaska. The Iliamna quadrangle is immediately north of the study area, and the Ugashik and Karluk quadrangles are immediately south of the study area. Physiographic provinces, major faults, Quaternary volcanoes, and major geographic features of the Alaska Peninsula are shown for reference (after Beikman, 1980).

(Detterman and others, 1976). It is mainly a highangle reverse fault. In the Katmai area, Jurassic intrusive rocks on the northwestern side of the fault are juxtaposed with Mesozoic sedimentary rocks on the southeastern side of the fault. Detterman and others (1976) state that the Bruin Bay fault was intermittently active from Late Jurassic to middle Tertiary time. Detterman and Hartsock (1966) and Detterman and Reed (1980) have suggested that as much as $65 \mathrm{~km}$ of left-lateral displacement has also occurred. Much of the area west of the Bruin Bay fault is covered by glacial deposits (Riehle and Detterman, in press) and is referred to as the Nushagak-Bristol Bay Lowlands province (Wahraftig, 1965).

\section{Mineral Occurrences in the Alaska Peninsula Region}

The Katmai study area is a transition zone between the Tertiary porphyry environment of the Alaska Peninsula to the south, and the syngenetic, skarn, and polymetallic vein mineral occurrences to the north. We show the distribution of the major mineral occurrences in figure 2 and briefly describe several of these occurrences below. Detailed geologic descriptions of the new mineral occurrences as well as their geochemical signatures are given in Church and others (in press); data on other previously described occurrences can be found in the original references. 
Mineral occurrences south of the Katmai study area are generally fit the porphyry copper and porphyry copper-molybdenum mineral deposit model types (Cox, 1986a,b). In both the ChignikSutwik Island AMRAP study (Cox and others, 1981) and the Ugashik-Karluk AMRAP study (Church, Detterman, and Wilson, 1989), porphyry copper mineral occurrences and deposits are associated with early Tertiary to Quaternary intrusive rocks of intermediate composition that intrude marine and nonmarine sedimentary clastic rocks. Six porphyry copper or porphyry copper-molybdenum prospects have been described (Cox and others, 1981) and areas that have mineral resources for these types of deposits have been outlined in both study areas. Several of these occurrences have been drilled and found to have copper, molybdenum, and base-metal resources, but reserve data are not generally available to the public (Hollister, 1978; Cox and others, 1981; Church, Detterman, and Wilson, 1989). Hollister (1978) summarized published data on four additional porphyry copper prospects on the Alaska Peninsula south of the Chignik-Sutwik Island study area, one of these prospects is the Pyramid Peak prospect on Unalaska Island which has produced some gold (Berg and Cobb, 1967). Wilson and others (1988) also describe similar porphyry copper prospects in the Port Moller-Stepovak Bay AMRAP study area that include the Pyramid Mountain and Ivanof prospects.

Occurrences of the porphyry copper-gold mineral deposit model type (Cox, 1986c) have also been described on the Alaska Peninsula. One porphyry copper-gold prospect of Oligocene age, the Rex prospect, has been described from the UgashikKarluk AMRAP study area (Church, Frisken, and Wilson, 1989). Field investigations by Kennecott indicate small reserves of copper with byproduct gold $(0.7 \mathrm{~g} /$ ton gold at 1 percent copper). Cominco has recently released information on a new porphyry copper-gold prospect, the Pebble Beach prospect in the Iliamna quadrangle, that contains an estimated 200 million tons of copper ore at 0.4 percent copper and $0.012 \mathrm{oz} /$ ton $(0.37 \mathrm{~g} / \mathrm{ton})$ gold (Danielson, 1991).

Two occurrences of the porphyry molybdenum mineral deposit model type (Theodore, 1986) of late Miocene to Pliocene age have also been described, the Warner Bay porphyry occurrence in the ChignikSutwik Island study area (Cox and others, 1981) and the Mike prospect in the Ugashik-Karluk study area (Church, Detterman, and Wilson, 1989; Church, Frisken, and Wilson, 1989). The Mike prospect has been drilled and is estimated to contain more than
25 million tons of ore at 0.2 percent $\mathrm{MoS}_{2}$ (Church, Detterman, and Wilson, 1989). Molybdenum and precious-metal-bearing quartz veins may be a polymetallic vein expression of this type of mineralization at depth. Such an occurrence is described at Cape Kubugakli (fig. 2) where quartz veins containing stibnite, molybdenite, galena, and tetrahedrite (Smith, 1925) occur in late Tertiary hypabyssal intrusions (Detterman and others, 1987). Placer gold was produced from one stream draining the area (Church, Detterman, and Wilson, 1989). On the basis of the geologic and geochemical data from this deposit, Church, Detterman, and Wilson (1989) interpreted this occurrence to be a polymetallic vein mineral deposit (Cox, 1986d). Additional pelymetallic vein occurrences are described in the Chignik-Sutwik Island study area (Cox and others, 1981) and polymetallic veins may be present throughout much of the Chignik-Sutwik Island and Ugashik-Karluk AMRAP study areas.

Precious-metal epithermal veins, exemplified by the Apollo Mine and the Shumagin prospect on Unga Island, also represent a viable exploration target on the Alaska Peninsula. These deposits are found in near-vertical quartz veins hosted by Oligocene lava flows and domes, mainly of andesitic composition (Wilson and others, 1988). They occur along or near through-going regional linear shear zones that are composed of localized quartz veins in silicified volcanic rocks (White and Queen, 1989). The Apollo Mine produced an estimated $130,000 \mathrm{oz}$ of gold $(3,469 \mathrm{~kg}$, Green and others, 1989) and lesser amounts of silver, copper, lead, and zinc between 1893 and 1908 from an estimated 500,000 tons of ore. Ore reserves at the Shumagin prospect are 270,000 tons at $16.8 \mathrm{~g} /$ ton gold and $68 \mathrm{~g} /$ ton silver (Wilson and others, 1988). W.H. White (oral commun., 1990) has classified these deposits as adularia-sericite type, epithermalgold quartz veins (Heald and others, 1987). At Battle Lake, just north of the Katmai study area, Detterman and Reed (1980) also described a precious-metal-bearing quartz vein associated with a small Tertiary intrusion; we classify the Battle Lake occurrence as a precious-metal-rich polymetallic vein (mineral deposit model type 25b; Mosier and others, 1986).

Several lode prospects for copper and gold have been described north of the Katmai study area. These occurrences are chiefly in contactmetamorphic zones in rocks northwest of the Bruin Bay fault where skarns have developed in Triassic limestone adjacent to Tertiary plutons. The Crevice Creek prospect is a skarn that formed along the 
contact between the Kamishak Formation and greenstone of the Talkeetna Formation. It contains both disseminated and lode pyrite and chalcopyrite. Mather (1925) reported that copper, silver, and gold were recovered from a one-ton shipment of highgrade chalcopyrite ore mined from this prospect. Nearby on Sargent Creek, lodes of magnetite are present as quartz-magnetite masses within epidotegarnet tactite formed in the upper chert-rich member of the Kamishak Formation. Geologic observations similar to those reported at Sargent Creek are also described at the Dutton claim (Martin and Katz, 1912) as well as elsewhere along the strike of the Kamishak Formation in the Iliamna quadrangle (Detterman and Reed, 1980).

The Kasna Creek prospect is a low-grade copper-iron deposit consisting largely of disseminated to massive hematite and magnetite with lesser amounts of pyrite, chalcopyrite, and minor sphalerite in a tactite developed at the contact with a Tertiary intrusion (Nelson and others, 1985). Assays from channel samples indicate resources of iron and copper with byproduct amounts of zinc, silver, and gold (Warfield and Rutledge, 1951); ore reserves have not been released. Concentrations of sulfides are mostly restricted to metasomatic contact zones within the Kamishak Formation. These occurrences are associated with the Late Cretaceous to early Tertiary intrusive rocks of the AlaskaAleutian Range batholith north of the Katmai study area and are best characterized as copper-rich iron skarns (Cox, 1986e).

Lead, silver, and zinc are found in galena-sphalerite veins in brecciated limestone of the Kamishak Formation at the Duryea prospect in the Iliamna quadrangle. Martin and Katz (1912) described small galena-sphalerite lodes that occur along fissures in limestone cross-cut by numerous small dikes. Galena, sphalerite, and minor pyrite are disseminated in the limestone. This occurrence best fits the description of a zinc-lead skarn mineral deposit model type (Cox, 1986f).

A gold-rich, Kuroko massive sulfide deposit has been described in rocks of the Lower Jurassic Talkeetna Formation from the Iliamna quadrangle. The Johnson River prospect is a discordant stockwork in submarine tuff and breccia. Steefel (1987) reported inferred resources, on the basis of drilling, of $1-2$ million tons grading $0.27 \mathrm{oz} /$ ton (8.4 g/ton) gold, 7 percent zinc, 0.7 percent copper, and 0.7 percent lead. Similar Kuroko massive sulfide occurrences also have been described in rocks of the Talkeetna Formation from the Talkeetna Mountains (Newberry, 1986).
Reed and Detterman (1965) described two iron eccurrences, both of which contain magmatic magnetite, associated with the rocks of the AlaskaAleutian Range batholith in the Iliamna quadrangle. At Frying Pan Lake, a magnetite-rich breccia body is along the margin of a Jurassic pluton. The breccia, which is composed almost entirely of magnetite-bearing pyroxenite fragments, was emplaced during the later Jurassic intrusive event (Reed and Detterman, 1965). The magnetite is titaniferous and the iron content varies between 16 to 24 percent. A second magnetite occurrence, the Pile Bay locality at the north end of Iliamna Lake, is a magnetite-rich hornblendite. Magnetite is present primarily as disseminated grains making up as much as 15 to 20 percent of the rock (Reed and Detterman, 1965). The syngenetic magnetite occurrences described from Frying Pan Lake and Pile Bay have characteristics of the Bushveld Fe-TiV mineral deposit model (Page, 1986). These are the only mineral occurrences associated with the Jurassic batholith (Detterman and Reed, 1980; Church and others, in press).

\section{INTERPRETATION OF AEROMAGNETIC DATA FROM PART OF THE NAKNEK QUADRANGLE}

No new aeromagnetic data were acquired during the Katmai AMRAP study. Andreasen and others (1963a) published aeromagnetic data from part of the Naknek quadrangle; their results are shown on plate I. The data were compiled along continuous flight lines at about a $3 \mathrm{~km}$ spacing. Our interpretation of these aeromagnetic data was guided by the interpretation of the aeromagnetic data from the Ugashik and Karluk quadrangles by Case and others (1988). The aeromagnetic anomalies published and interpreted by Case and others (1988) corresponds closely with that of a companion study of parts of the adjacent Ugashik and Karluk quadrangles (Andreasen and others, 1963b).

Case and others (1988) summarized magnetic susceptibilities measured on rocks collected from the Alaska Peninsula. In general, many Mesozoic and Tertiary sedimentary rocks have very low magnetic susceptibilities and produce magnetic lows on the aeromagnetic map. Jurassic volcanic rocks have high magnetic susceptibility resulting in characteristic high-frequency, high-amplitude patterns on the aeromagnetic map. Tertiary and 
Quaternary volcanic rocks have a highly variable magnetic susceptibilities, but generally are moderately magnetic and produce high-frequency, but moderate-amplitude anomalies on the aeromagnetic map. Jurassic and Tertiary intrusive rocks also have highly variable magnetic susceptibilities; more mafic rocks have a high magnetic susceptibility and produce intense lobate aeromagnetic anomalies, whereas igneous rocks of intermediate composition produce less intense lobate anomalies on the aeromagnetic map. Unfortunately, there is only minor overlap of mappable geologic units and the aeromagnetic data in the Katmai study area (plate I). No new magnetic susceptibility measurements have been made on rocks collected from this study area to verify our interpretation. However, published studies of the aeromagnetic character of these same rock units in the Talkeetna Mountains quadrangle (Csejtey and Griscom, 1978) and the Cook Inlet area (Fisher, 1981) provide insight on the magnetic signature of these rocks units in both areas. In spite of these deficiencies, the aeromagnetic data provide important constraints on the mineral resources of this part of the Katmai study area.

The major aeromagnetic patterns (Andreasen and others, 1963a) are interpreted as buried sedimentary, volcanic, and metavolcanic rocks that trend northeast-southwest in the study area. The area of the aeromagnetic map is within the Nushagak-Bristol Bay Lowlands and is mostly covered by glacial alluvium (Riehle and Detterman, in press); there are only a few isolated outcrops that provide any direct evidence for our interpretation. The sedimentary and volcanic rocks have been intruded by several highly magnetic plutons, interpreted as deeply buried mafic bodies, as well as several shallow, less magnetic intrusive bodies of intermediate composition.

The striped magnetic anomaly pattern (Andreasen and others 1963a) in the southeast corner of the aeromagnetic map (area SV1) is interpreted to be intercalated mafic volcanic (FC?) and nonmagnetic sedimentary (Fk?) rocks. The sedimentary rocks are generally nonmagnetic, and show small amplitudes as much as about $200 \mathrm{nT}$ (1 $\mathrm{nT}=1$ gamma). Similar magnetic patterns are coincident with Upper Triassic volcanic rocks in the Talkeetna Mountains quadrangle (anomaly 18, Csejtey and Griscom, 1978), suggesting that the Cottonwood Bay Greenstone may be responsible for the strong linear magnetic highs in area SV1. At Blue Mountain in T. 24 S.-T. 25 S., R. 43 W., a small outcrop of the Cottonwood Bay Greenstone
(FC) which coincides with a steep magnetic gradient within area SV1, supports this interpretation. Furthermore, gently folded Triassic sedimentary and mafic volcanic rocks overlying Jurassic intrusive rocks (Jgr, Jgd, and Jqd) of the Alaska-Aleutian Range batholith also would be consistent with the geology in T. 23 S., R. 42 W.

Rocks in area SV1 grade northwestward into area $V_{1}$ where they have an anomalously high magnetic expression that has amplitudes of 500-800 nT. Rocks in area $V_{1}$ are interpreted to be volcanic rocks of the Jurassic Talkeetna Formation ( $\mathrm{Jt}$ ) on the basis of outcrops of the Talkeetna Formation that have similar magnetic expression in T. 20 S.-T. 21 S., R. 42 W.-R. 43 W. The magnetic character is also very similar to that of the Talkeetna Formation in the Talkeetna Mountains quadrangle (anomaly 28; Csejtey and Griscom, 1978). At the southwestern end of area $V_{1}$, the magnetic anomalies are more subdued. If rocks of the Talkeetna Formation (Jt) are present throughout the entire area of $\mathrm{V}_{1}$, they are deeply buried. This possibility is indicated by the "hinge line" shown on plate I southwest of anomaly JTg1. At this "hinge line" the rocks of the Talkeetna Formation (Jt) appear to be folded, dipping steeply toward the southwest.

Two areas of nonmagnetic rocks (SV2, $\left.\mathrm{SV}_{3}\right)$ which are indicative of the magnetic character of the rocks in area $\mathrm{SV}_{1}$ are within area $\mathrm{V}_{1}$ just northwest of the outcrop patterns of the Talkeetna Formation (Jt) in T. 21 S., R. 45 W.-R. 46 W. (SV2) as well as in T. 20 S.-T. 21 S., R. 42 W.-R. 44 W. (SV3). These rocks are interpreted as overlying or intercalated sedimentary rocks within the Talkeetna Formation (Jt), similar to the geology in T. 23 S., R. $42 \mathrm{~W}$.

Rocks of the Kakhonak Complex (JPzk) crop out within T. 18 S., R. 43 W. Amplitudes of the associated magnetic anomalies range to as much as $1,000 \mathrm{nT}$. The aeromagnetic pattern of the rocks of the Kakhonak Complex is characterized by linear bands having steep gradients. The strongly magnetic, linear pattern of areas $V_{2}$ and $V_{3}$ are interpreted to represent subcrops of this metavolcanic unit. The elongate magnetic highs (such as in area V4) within area V1 (T. 19 S., R. 44 W.) are also interpreted to indicate a more magnetic metamorphosed volcanic unit, possibly rocks of the Kakhonak Complex (JPzk).

North and east of areas $V_{1}$ and $V_{2}$, the aeromagnetic map changes to a broader, somewhat more open character having amplitudes as much as $400 \mathrm{nT}$. Areas V5 and V6 are interpreted to 
represent the Tertiary volcanic rocks north of Naknek Lake (andesite unit Tva; basalt unit Tvb) that crop out in the northwest part of the geologic map. Only one small outcrop of Tertiary andesite (Tva) is in T. 17 S., R. 43 W. and two outcrops of Tertiary basalt (Tvb) are in T. 15 S.-T. 16 S., R. 42 W.-R. $43 \mathrm{~W}$. within the aeromagnetic map. A narrow, east-northeast-trending, isolated band of negative aeromagnetic anomalies ( $R 1)$, which may represent either Tertiary sedimentary rocks (Ts) or reversely magnetized(?) basalt flows (Tvb), are in area V6. Although no measurements of magnetic susceptibility have been made for these particular rock units, susceptibility measurements from Tertiary volcanic rocks collected from the Alaska Peninsula (Case and others, 1988) are generally intermediate and would produce moderate aeromagnetic anomalies similar to those observed in areas V5 and V6.

Plutons of three possible types are interpreted from the aeromagnetic data, although no plutons crop out within the boundaries of the aeromagnetic study. There are three strongly magnetic, lobate bodies ( $\mathrm{JTg}_{1}, \mathrm{JTg}_{2}$, and $\mathrm{JTg} 3$ ) that have strong magnetic gradients with magnetic amplitudes in excess of $1,200 \mathrm{nT}$ that are interpreted as deeply buried mafic intrusions (unit Jgb?). They have the same magnetic character as anomaly 3 in the Nushagak-Bristol Bay Lowlands in the Ugashik quadrangle, which Case and others (1988) attribute to dioritic or gabbroic bodies buried at a depth of 3 or more $\mathrm{km}$. This interpretation is also consistent with the presence of gabbroic bodies in the Jurassic Alaska-Aleutian Range batholith reported by Detterman and Reed (1980) in the Iliamna quadrangle. The west side of anomaly $\mathrm{JTg}_{2}$ appears to be faulted down along a north-trending lineament. The magnetic character of anomaly JTg2 suggests that the top of this intrusive body may be within 2 $\mathrm{km}$ of the surface.

A Jurassic intrusive body is suggested by the lobate character of anomaly Ji in area SV1. Fisher (1981) states that Jurassic and Tertiary plutons of dioritic to quartz dioritic composition in the Cook Inlet area produce strongly magnetic anomalies and steep gradients where they are near the surface. A similar magnetic character is indicated by exposed Jurassic granodiorite and associated roof pendants underlying anomaly 26 in the Talkeetna Mountains quadrangle (Csejtey and Griscom, 1978). Anomaly $\mathrm{Ji}$ has an amplitude of about $400 \mathrm{nT}$ above the surrounding magnetic basement rocks which is higher than the magnitude of aeromagnetic anomalies associated with deeply buried intrusions in the Ugashik and Karluk quadrangles (anomaly 2, TJi, in the Nushagak-Bristol Bay Lowlands; Case and others, 1988). Anomaly Ji may represent a magnetic Jurassic intrusion buried at a shallow depth or, alternatively, it may represent more magnetic units of the buried Talkeetna Formation ( $\mathrm{Jt}$ ).

In area V6, several small lobate magnetic anomalies are interpreted as buried plutons (JTi1, JTi2, JTi3, and JTi4). They may represent buried plutonic equivalents of the Tertiary andesite exposed north of Naknek Lake. There are no constraints on the age of these inferred plutons.

\section{MINERAL PROSPECTS, CLAIMS, AND OCCURRENCES IN THE MOUNT KATMAI, NAKNEK, AND WESTERN AFOGNAK QUADRANGLES}

In 1918, the majority of the Katmai study area was declared a National Monument and, thus, these federal lands were withdrawn from mineral exploration. As a result, there has been only limited exploration for minerals in much of the Katmai study area (Cobb, 1972a,b,c; MacKevett and Holloway, 1977). Atwood (1911) reported that there were no known mineral prospects in the Katmai study area through 1908. Martin (1920) reported exploration activity at the Kukak Bay copper prospect (table 1, no. 12). Cobb (1980) referenced an unsubstantiated magazine article, published in March 1918, that claimed ore grades of 4-6 percent copper with byproduct gold and silver at the Kukak Bay prospect. This occurrence was not found during our study. Several new mineral occurrences have been identified on the basis of our current work in the Katmai study area and are reported here in table 1. There is no record of production from any of these prospects. A few placer gold claims and lode copper prospects have been reported, the most recent summary of which is by MacKevett and Holloway (1977). Placer claim activity is reported in table 2; some gold was apparently produced from the American Creek claim (no. 23) although no production records are available. The pumice claims (nos. 27-32) were filed following World War II and a small amount of pumice was shipped to Anchorage for the manufacture of lightweight building blocks (Moxham, 1951; Eckhart and Plafker, 1959, p. 34). In this report, we include all the claim information through July 1990 , available 
from both the U.S. Bureau of Land Management and the U.S. Bureau of Mines files (U.S. Bureau of Mines, 1973). The Tri Beauty no. 9 claim (table 2, no. 20) is the only active claim in the Katmai study area.

\section{METALLIC MINERAL RESOURCES}

The mineral resource assessment of the Katmai study area is based on an integrated interpretation of the geology (Riehle and others, in press; Riehle and Detterman, in press), geochronology (Shew and Lanphere, in press), exploration geochemistry (Church, Bailey, and Riehle, 1989; Church and Arbogast, 1989; Church and Motooka, 1989; Riehle and others, 1989; Church and others, in press), and mineralogy of the nonmagnetic, heavy-mineral concentrates panned from stream sediments (Church and Bennett, 1989) included in the Mount Katmai folio. In addition, we have utilized the aeromagnetic data from Andreasen and others (1963a) to evaluate the mineral resources of part of the Naknek quadrangle. There is no aeromagnetic data from the Katmai study area east of the boundary shown on the map. On the mineral resources map, we show localities of the mineral prospects, claims, and occurrences (table 1), localities of the placer claims (table 2), and mineralresource tracts described below. A summary of the geologic features and the geochemical and mineralogical data used in defining the tracts and subtracts is presented in table 3. In this mineral resource assessment, we have made our interpretations of mineral deposit types based mostly on the mineral deposit models described in Cox and Singer (1986). Areas of mineral potential are summarized in table 4. Resource estimates apply only to the near surface occurrence of possible ore deposits; because of the absence of aeromagnetic data from most of the Katmai study area, we are limited in this mineral resource assessment to the surficial geologic observations and inferences in this report.

\section{Mesozoic volcanic environment}

Three units--the Cottonwood Bay Greenstone (FC), the Talkeetna Formation ( $\mathrm{Jt}$ ) and the Kakhonak Complex (JPzk)--contain submarine volcanic rocks of predominantly Mesozoic age. The Cottonwood Bay Greenstone crops out in the southwestern part of the Katmai study area. These rocks are submarine basalt flows (RC) that are transitional and interbedded with the Kamishak Formation (下k). No evidence of either hydrothermal or volcanic vents were found during the field mapping. The aeromagnetic data are too widely spaced to accurately detect point-source aeromagnetic anomalies within area $\mathrm{SV}_{1}$ that might indicate concealed massive sulfide deposits. Although the outcrop and projected distribution of this unit in area $S_{1}$ is permissive for the occurrence of Cyprus-type massive sulfide deposits, our geologic and geochemical studies do not indicate areas favorable for such deposits in rocks of the Cottonwood Bay Greenstone (Th).

The volcanic rocks of the Talkeetna Formation (Jt) crop out in a belt west of the Alaska-Aleutian Range batholith in the southern part of the Katmai study area and converge with the batholith at the northern boundary of the study area where they are found as roof pendants in the batholith. They are projected into area $V_{1}$ on the aeromagnetic map of the eastern part of the Naknek quadrangle. These volcanic rocks are generally submarine(?), basaltic to andesitic in composition, and represent a Jurassic volcanic arc (Reed and Lanphere, 1973). The aeromagnetic data are too widely spaced to accurately detect point-source aeromagnetic anomalies within area $V_{1}$ that might indicate concealed massive sulfide deposits. Although the outcrop and projected distribution of this unit in area $V_{1}$ is permissive for the occurrence Kuroko massive sulfide deposits, our geologic and geochemical studies do not indicate areas favorable for the occurrence of such deposits in the rocks of the Talkeetna Formation (Jt).

The Kakhonak Complex (JPzk), which contains metamorphosed volcanic rocks, some of which may be lithologically equivalent to the Cottonwood Bay Greenstone or the Talkeetna Formation, also shows no evidence of syngenetic, massive sulfide occurrences in the Katmai study area (Church and others, in press). Rocks of the Kakhonak Complex are also projected beneath the glacial cover in areas $\mathrm{V}_{2}, \mathrm{~V}_{3}$, and $\mathrm{V}_{4}$ in the Naknek quadrangle. Although the area underlain by these metamorphosed rocks is permissive for the occurrence of massive sulfide deposits, our geologic and geochemical studies do not indicate areas favorable for the occurrence of such deposits in the rocks of the Kakhonak Complex (JPzk).

In summary, the rocks of the three submarine volcanic units ( $\mathrm{Rc}$, Jt, and JPzk) of predominantly Mesozoic age in the Katmai study area are all permissive for the occurrence of undiscovered 
massive sulfide deposits. However, the paucity of identifiable volcanic vents, the absence of geochemical anomalies as well as the absence of high, site-specific aeromagnetic anomalies in the eastern Naknek quadrangle, where we have aeromagnetic data, suggests that there is less than a one percent chance that an undiscovered massive sulfide deposit exists within the Katmai study area.

\section{Triassic carbonate depositional environment}

Outcrops of the Triassic Kamishak Formation (下k) are found in the southwest part of the Katmai study area and are projected beneath glacial cover in the eastern Naknek quadrangle in area SV1. In addition, the Kakhonak Complex (JPzk) also contains carbonate rocks that may have been derived from the Kamishak Formation. During our reconnaissance geochemical studies, we observed no evidence of mineralization in the field and did not detect any geochemical anomalies that could be related to syngenetic or base-metal replacement mineral occurrences in these rocks in the Katmai study area. The sedimentary section is thin and there are no base-metal replacement deposits known in southwestern Alaska (MacKevett and Holloway, 1977).

\section{Jurassic, Cretaceous, and Tertiary sedimentary environment}

The clastic rocks of the Naknek Formation (Jn) represent deposition on the continental shelf and adjacent fluvial and littoral zones. The clastic rocks of the Staniukovich (Ks), Herendeen (Kh), Pedmar $(\mathrm{Kp})$, and Kaguyak (Kk) Formations represent separate cycles of emergence and erosion, and of submergence and deposition. These formations represent a marine depositional environment. The Tertiary clastic rocks of the Copper Lake Formation (Tc), the Hemlock Conglomerate (Th), and the Tertiary sedimentary rocks (Ts) represent a fluvial depositional environment. Although plant fossils that might serve to precipitate uranium are present in these beds, there are no known source rocks for uranium in the area. Thus these rocks are not favorable for the occurrence of sandstone-hosted uranium deposits. Many of the geochemical anomalies that are found in the Katmai study area where these rocks crop out can be related to Tertiary epithermal mineralization. We conclude that no syngenetic metalliferous deposits are associated with the rocks formed in the sedimentary environment in the Katmai study area.

\section{Jurassic plutonic environment}

The plutonic rocks (Jgr, Jgd, Jqd, and Jgb) that crop out west of the Bruin Bay fault represent an early calc-alkaline magmatic arc (Reed and Lanphere, 1969, 1973). The Jurassic plutons are emplaced within and are consanguineous with the Talkeetna Formation (Reed and Lanphere, 1973, p. 2588). Detterman and Reed (1980, p. 21-22) found magmatic, layered magnetite deposits directly associated with the gabbroic to dioritic intrusive rocks of the Alaska-Aleutian Range batholith in the Iliamna quadrangle. Reed and others (1983, p. $1239)$ and Reed and Lanphere (1973, p. 2606) argue on the basis of ${ }^{87} \mathrm{Sr} /{ }^{86} \mathrm{Sr}$ data, the major element chemistry, and geologic data that the Jurassic plutonic arc represents the deep seated part of a primitive oceanic island arc. In our geologic and geochemical studies of the Katmai region, we have not found significant geochemical or geologic indications of mineralization associated with Jurassic plutonic rocks of the Alaska-Aleutian Range batholith. However, we found one site where a sample from a quartz vein in the Jurassic granitic rocks on the north side of Becharof Lake (table 12, Church and others, in press) contained 5,000 ppm copper; this site may be indicative of an isolated polymetallic vein occurrence. In general, we found no evidence of mineral occurrences in either the plutonic rocks or the older rocks in the roof pendants enclosed by these plutons in the Katmai study area (Church and others, in press).

\section{Early to middle Tertiary volcanic rocks from north of Naknek Lake}

Early to middle Tertiary $(25.0 \pm 1.6$ to 44.3 $\pm 0.8 \mathrm{Ma}$; Shew and Lanphere, in press) subaerial andesitic and basaltic rocks crop out north of Naknek Lake. These same volcanic rocks are projected beneath glacial deposits in area V6 in the northeastern part of the Naknek quadrangle. Much of this part of the Katmai study area is covered by glacial deposits (Riehle and Detterman, in press). These volcanic rocks generally contain incipient secondary chlorite, but otherwise show little other evidence of hydrothermal alteration. A single altered sample from east of Sugarloaf Mountain contains $15 \mathrm{ppm}$ molybdenum; the protolith was probably a silicic tuff or hypabyssal dome that has 
been recrystallized to quartz and zeolites and is cut by thin veins of quartz and chlorite. Drainage basins from the area contain isolated anomalies of molybdenum, tungsten, copper, zinc, gold, and silver (Church, Bailey, and Riehle, 1989; Church and Arbogast, 1989). Hydromorphic anomalies of iron-manganese-arsenic were also found in the area (Church and Motooka, 1989) and are interpreted to represent the iron-oxide coatings prevalent in the volcanic rocks in this area (Church and others, in press). The Rex, a porphyry copper-gold prospect from the Ugashik-Karluk study area described earlier in this report, is in volcanic and hypabyssal rocks of middle Tertiary (Oligocene) age. Gold was panned from drainage basins west and north of Sugarloaf Mountain (Church and Bennett, 1989). Placer gold claims (table 2, nos. 22 and 23) have also been filed in this area. Likewise, gold was found in many of the drainages surrounding the Rex prospect (Frisken and others, 1988; Frisken, Church, and Willson, 1988). Although the geologic and geochemical data are not sufficient to define a mineral resource tract, on the basis of the age relationships, the presence of weak iron-manganesearsenic and somewhat more sporadic copper, tungsten, and gold anomalies in volcanic rocks of the same age as the Rex porphyry copper-gold deposit, and the presence of Tertiary(?) plutons (JTi1, JTi2, JTi3, and JTi4) interpreted from the aeromagnetic data in the northeastern part of the Naknek quadrangle, we suggest that the northwestern part of the Mount Katmai and the northeastern part of the Naknek quadrangle (area V6), underlain by early to middle Tertiary volcanic rocks north of Naknek Lake have potential for concealed, undiscovered porphyry copper-gold deposits.

\section{Middle Tertiary plutonic rocks of the Alaska-Aleutian Range batholith}

Middle Tertiary plutons $(26.0 \pm 0.8$ to $37.6 \pm$ 1.1 Ma; Shew and Lanphere, in press), chiefly of granodiorite and quartz monzodiorite but also including tonalite, quartz diorite and gabbro, crop out in the Kulik Lake area, tract 1 , and intrude the Bruin Bay fault. The boundary of tract 1 is defined on the basis of the outcrop pattern of middle Tertiary granodiorite (Tgd) and quartz diorite (Tqd), their alteration halos, and the associated geochemical anomaly patterns (plates 2 and 3 ; Church and others, in press). Mineral occurrences in the Kulik Lake area include the polymetallic vein occurrences at Kulik Lake Gold (no. 5), Kulik Kopper [sic] prospect (no. 6), Oakley Peak (no. 7), an unnamed occurrence (no. 8), and the Kami prospect (no. 9). Geologic and geochemical attributes of tract 1 are summarized in table 3 . It is conjectural that all of the mineralized rock in tract 1 is associated with the middle Tertiary igneous rocks. However, the spatial association of mineral occurrences and geochemical anomalies with the middle Tertiary plutons and the paucity of mineralized rock associated with the Jurassic magmatism in both the Mount Katmai and the Iliamna quadrangles as discussed above is strong supporting evidence that middle Tertiary magmatism was the cause of the mineralization we observe in tract 1 . Although geologically feasible, porphyry copper occurrences are considered unlikely in tract 1 because of the absence of large areas of hydrothermal alteration and the absence of zoned geochemical patterns in the stream drainages (Church and others, in press) that would be indicative of the larger size hydrothermal systems associated with porphyry copper deposits.

Polymetallic vein occurrences in tract 1 are characterized by pyrite-bearing quartz veins and disseminated pyrite in metamorphosed rocks in the roof pendants in the Jurassic plutons, in the Jurassic plutons themselves, and in the middle Tertiary plutons. Quartz-sericite alteration is generally present in the younger plutons where quartz veins and disseminated sulfide minerals have been observed. Similar geologic features were observed where polymetallic veins are associated with middle Tertiary plutons in the Iliamna quadrangle (Detterman and Reed, 1980).

The Kulik Lake Gold vein (table 3) is a small outcrop of sheeted quartz veins along the contact between two Jurassic plutons (Jqd and Jgd). Quartz veins occupy as much as fifty percent of the area of the exposure (several tens of square meters) and some of the quartz veins contain as much as 50 percent fine-grained pyrite. Gold contents generally range between 0.05 and $0.5 \mathrm{ppm}$ gold with a maximum measured gold content of $4.4 \mathrm{ppm}$ (table 13, Church and others, in press). Our follow-up field studies of the area are insufficient to define the extent of this occurrence.

Skarn occurrences in the Iliamna quadrangle are associated with the Late Cretaceous to Tertiary plutons of the Alaska-Aleutian Range batholith (Detterman and Reed, 1980, p. 76). As described in this report, the skarns from the Iliamna and Lake Clark quadrangles are found in contact metamorphic zones with the limestone of the Kamishak Formation 
which has been removed by erosion from this part of the Katmai study area. One sample of skarn has been described from the contact zone between the Tertiary quartz diorite (unit Tqd, dated between 35$37 \mathrm{Ma}$; Shew and Lanphere, in press) and the carbonate-cemented siltstone of the Herendeen Formation $(\mathrm{Kh})$, but this is a minor mineral occurrence (Church and others, in press). Because of the paucity of carbonate rocks in tract 1 , skarn occurrences are considered volumetrically unimportant in evaluating the mineral resources of tract 1.

Detterman and others (1979) reported one site in the Gertrude Creek drainage (T. 23 S., R. 42 W.) where magnetite and pyrite were found adjacent to an andesite dike in limestone. They suggest that these dikes are younger than the Jurassic batholithic plutons dated in this area. These data may be indicative of skarn occurrence.

Major-element chemical data from the middle Tertiary intrusive rocks from the Mount Katmai quadrangle (J.R. Riehle, unpub. data, 1990) are not consistent with those of the Late Cretaceous to early Tertiary McKinley sequence granites as defined by Lanphere and Reed (1985). Furthermore, we found no tin geochemical anomalies associated with the outcrop patterns of these rocks (Tgd and Tqd) in the Mount Katmai quadrangle. We conclude that there is no potential for tin resources associated with the middle Tertiary plutons in the Katmai study area.

\section{Tertiary and Quaternary volcanic-plutonic environment}

Mineral-resource tracts 2,3 , and 4 are associated with hypabyssal plutons, dikes, sills, and volcanic rocks of Tertiary to Quaternary age. Tract 2 is defined on the basis of geologic outcrop pattern of the deuterically altered Tertiary plutons (Tiu) west of the Aleutian Range crest and the associated geochemical anomaly patterns (Church and others, in press). Tract 3 is defined on the basis of geologic and geochemical data from the latest Tertiary and early Quaternary volcanic rocks (QTac) of the Kejulik volcanic field (Church, Frisken, and Wilson, 1989; Church and others, in press). Tract 4 is defined on the basis of the geologic outcrop pattern of the Tertiary volcanic, hypabyssal, and intrusive rocks (Ti) mapped on the east side of the Aleutian Range, and the pattern of geochemical anomalies spatially associated with them. The boundary between tracts 2 and 4 is obscured by the Quaternary volcanic rocks of the Aleutian volcanic arc and by the alpine glaciers present along the crest of the Aleutian Range. However, they are probably separable tracts because the geochemical anomalies in tract 4 are generally characterized by different geochemical associations than those in tract 2 (Church and Motooka, 1989; Church and others, in press).

Tract 2 has been divided at the Valley of Ten Thousand Smokes into subtracts $2 \mathrm{~A}$ and $2 \mathrm{~B}$ on the basis of favorable geochemical anomalies. In tract $2 \mathrm{~A}$, two mineral occurrences have been described (table 1, nos. 2 and 3). The geologic and geochemical attributes of this tract are summarized in table 3. At the Margot Creek Copper occurrence, the geochemical and geologic data fit the criteria used to define porphyry copper-molybdenum occurrences on the Alaska Peninsula (Cox and others, 1981). This occurrence is defined on the basis of a Cu-Mo-W geochemical anomaly associated with a pluton or hypabyssal plug (Tiu) that contains stockwork chalcopyrite and molybdenite in a potassic-altered tonalitic stock. The central potassic alteration zone at the Margot Creek Copper occurrence covers an area of only a few hundred square meters. No age data are available from this stock. Drainage basins surrounding this geochemical anomaly contain basemetal geochemical suites from zones of propylitically altered rock.

In contrast, geochemical anomalies in tract 2B are generally similar to those of the Ikagluik Creek occurrence (table 1, no. 4). Quartz veins are common and are spatially associated with dikes, sills, and plugs (Tiu) in tract $2 \mathrm{~B}$. One small stock in tract 2B has been dated at $2.64 \pm 0.04 \mathrm{Ma}$ (Shew and Lanphere, in press). A widespread base-metal geochemical anomaly is present throughout the area of tract 2B (Church and others, in press, plate 3). Several drainage basins also contain geochemical anomalies of the porphyry copper-molybdenum suite (see plate 2, Church and others, in press). Tract 2 has potential for both porphyry copper and polymetallic vein deposits.

Tract 3 is open to the south and is contiguous with tract $\mathrm{A6a}$ of the Ugashik-Karluk mineral resource assessment (Church, Detterman, and Wilson, 1989). The description of tract 3 in table 3 is based largely on geologic observations of the eroded volcanic neck in the Kejulik volcanic field and the geochemical signatures from the surrounding drainage basins. In the drainage basin where the volcanic neck is exposed (table 1, no. 1), we observed highly bleached rocks containing disseminated pyrite. The drainage basins 
surrounding this site contain base-metal anomalies that extend south into the Ugashik-Karluk study area (fig. 24, Church, Frisken, and Wilson, 1989). Geochronological data indicate an age range of 0.5 2.5 Ma for volcanic rocks from the tract (Shew and Lanphere, in press). Tract 3 has potential for polymetallic vein deposits that may overlie a concealed, undiscovered porphyry copper deposit.

Tract 4 is a large tract underlain by Tertiary and Quaternary volcanic rocks and associated hypabyssal intrusions east of the crest of the Aleutian Range. We have lumped all of the mineral occurrences in the area into a single tract because they all may be spatially associated with the Tertiary intrusive rocks (Ti). For ease of discussion, we have divided this tract into three subtracts on the basis of the geologic and geochemical data. The geologic attributes of each subtract are summarized in table 3 ; tracts $4 \mathrm{~A}$ and $4 \mathrm{C}$ contain more abundant geochemical anomalies. Tract $4 \mathrm{~A}$, in the Barrier Range, includes base- and precious-metal anomalies in Tertiary volcanic rocks (Tab) which have been extensively altered in this area. Tract 4B is an area between the Barrier Range and the Fourpeaked Mountain area that is underlain mostly by the Jurassic Naknek Formation (Jn) and Tertiary and Quaternary volcanic rocks (QTap, QTac, Qap, Qad, and Qac). Geochemical anomalies in tract 4B are of the same metal suite, but are more diffuse than the base- and precious-metal anomaly suites in either tracts $4 \mathrm{~A}$ or $4 \mathrm{C}$. Tract $4 \mathrm{C}$, the Fourpeaked Mountain area, is underlain mostly by the plutonic rocks (Ti) and hornfels-facies Mesozoic ( $\mathrm{Jn}, \mathrm{Ks}, \mathrm{Kh}$, $\mathrm{Kp}$, and $\mathrm{Kk}$ ) and Tertiary (Tc) sedimentary rocks. Boundaries between subtracts $4 \mathrm{~A}, 4 \mathrm{~B}$, and $4 \mathrm{C}$ are shown as dashed lines, but are arbitrary because the changes between subtracts are gradational. We suggest that the controlling feature that results in differing geologic and geochemical attributes in these subtracts is the presence of Tertiary intrusive rocks in the subsurface.

Tract 4A contains a diverse suite of mineral occurrences and geochemical anomalies. At least three discrete subareas have been defined in tract 4A on the basis of their geologic and geochemical attributes (table 3); boundaries between these subareas are also gradational. Gold-bearing quartz veins in tract $4 \mathrm{~A}$ have two distinctive geochemical signatures. In the Kuliak Bay-Katmai River subarea, drainage basins underlain by hornfels-facies sedimentary rocks that have been cut by small dikes and sills contain cinnabar in the nonmagnetic, heavy-mineral concentrates (Church and Bennett, 1989). Numerous quartz veins are found throughout this subarea. The geologic and geochemical data make this subarea favorable for the occurrence of gold-bearing quartz vein deposits. We also found evidence for several gold-bearing quartz vein occurrences in the Katmai Lakes-Hagelbargers PassDakavak Lake subarea (Church and others, in press). Mineral occurrences at the Hagelbargers Pass and the Dakavak Lake localities (table 1, nos. 13 and 14) are gold-bearing quartz veins. Pyrite is present in banded and brecciated quartz veins. At Dakavak Lake, gold contents in veins are commonly in the ppb range $(0.2 \mathrm{ppm})$ and have a maximum detected concentration of 5 ppm (table 17, Church and others, in press). At Hagelbargers Pass, gold contents range from 0.05 to $0.45 \mathrm{ppm}$ and reach a maximum detected concentration of $4.4 \mathrm{ppm}$ (table 14, Church and others, in press). This gold-bearing quartz vein has a distinctive Mo-Ag-Au-As-Sb geochemical signature that is interpreted to be a polymetallic vein expression of a concealed porphyry molybdenum deposit (Church and others, in press). This geochemical signature was observed in the UgashikKarluk study area at the Cape Kubugakli polymetallic vein occurrence described above (fig. 2). Two late Tertiary porphyry molybdenum occurrences (fig. 2) have also been described from the Alaska Peninsula (Cox and others, 1981; Church, Frisken, and Wilson, 1989).

Polymetallic vein occurrences are described at two localities in tract 4A. At both the Soluka Creek and Dakavak Bay occurrences (table 1), quartz veins and disseminated pyrite is present in contactmetamorphosed wall rock along the margins of the Tertiary plutons. At Soluka Creek (table 1, no. 15), propylitic alteration and quartz veins were observed along the north side of the pluton (Church and others, in press). At Dakavak Bay (table 1, no. 16), propylitic alteration and quartz veins were observed at several localities surrounding the pluton. Farther north in the Kukak Bay subarea, Cobb (1980) described workings at the Kukak Bay prospect (table 1 , no. 12), which consisted of an adit $55 \mathrm{~m}$ in length and a small shaft. Ore grades of 4-6 percent copper and byproduct gold and silver were reported but no reserves were given. We were unable to locate this prospect during the Katmai AMRAP study; the exact location of this prospect is not known. However, geologic and geochemical studies of the Kukak Bay subarea outlined drainage basins where there are significant geochemical anomalies on the north side as well as at the head of Kukak Bay (plate 3, Church and others, in press). Rock samples from this subarea contain both disseminated pyrite as well as pyrite in quartz veins. The Kukak Bay subarea of 
Tract 4A has potential for both polymetallic vein and porphyry copper deposits. We conclude that undiscovered polymetallic vein deposits are likely to occur in tract $4 \mathrm{~A}$; this area also has potential for concealed, undiscovered porphyry copper and porphyry molybdenum deposits.

Tract 4B, the Ninagiak River area (table 3), is mostly underlain by rocks of the Naknek Formation (Jn) and by Quaternary volcanic rocks. Except for a few vertical dikes that trend northwest, exposures of Tertiary plutonic rocks (Ti) are uncommon in tract 4B. Geochemical anomalies generally consist of only one or two elements and are mostly scattered, single-site anomalies (Church and others, in press). At one locality, we observed a quartz-breccia dike (table 3). The geologic attributes and geochemical data indicate that tract $4 \mathrm{~B}$ has potential for undiscovered polymetallic veins.

Tract $4 \mathrm{C}$, the Fourpeaked Mountain area on Cape Douglas (table 3), is underlain by Mesozoic and Tertiary rocks that have been broadly folded and pervasively fractured by the intrusion of a middle to late Tertiary pluton (unit Ti, 5-29 Ma; Shew and Lanphere, in press). North and west of Fourpeaked Mountain, drainage basin anomalies and geology are indicative of polymetallic veins (plate 4 , Church and others, in press). One large block of claims, the Wm. Douglas Group (table 1, no. 10) was filed in this area of tract $4 \mathrm{C}$. East and south of Fourpeaked Mountain, quartz veins contain a variety of sulfide minerals in the Tertiary intrusive rocks and immediately overlying hornfels. Southwest of Fourpeaked Mountain to Big River, quartz veins are found in a large area marked by prominent redbrown anomalies, widespread hydrothermal alteration, and geochemical anomalies indicative of both porphyry copper and polymetallic vein occurrences (plates 2 and 3, Church and others, in press). The Big River occurrence (table 1, no. 11) marks the locality of a small, propylitically altered pluton that contains pyrite, chalcopyrite, and sphalerite in quartz veins as much as $6 \mathrm{~cm}$ in width. This locality is typical of the type of mineralized rock observed between Big River and Fourpeaked Mountain. Tract $4 \mathrm{C}$ has potential for undiscovered polymetallic vein and porphyry copper deposits.

There also are isolated epithermal-vein, hot springs mineral occurrences associated with Quaternary volcanic rocks and deposits (Qac, Qad, and Qap). These localities have not been delineated in a separate tract; they are found along the length of the Aleutian volcanic arc between tracts 2 and 4 . One such locality is found near Mount Mageik, a second near Kejulik Pass and a third near Snowy
Mountain, where siliceous hot springs sinter and iron-oxide deposits have been found (tables 14 and 17; Church and others, in press). Geochemical data indicate that the crest of the Aleutian volcanic arc has potential for undiscovered hot springs epithermal gold and mercury deposits. However, this part of the Katmai study area is so heavily glaciated that these features are not generally preserved. Geologic evidence of hot springs activity, such as sinter and chalcedony in volcanic rocks, is present in the glacial boulders found at the headwaters of many stream drainages.

\section{Evaluation of placer resources in the Quaternary glacial and alluvial environment}

Quaternary glacial-alluvial deposits (Qs) have been investigated for possible placer accumulation of gold in the Katmai study area east of about $156^{\circ}$ W. longitude, but no new information is available for the Nushagak-Bristol Bay Lowlands province in the Naknek quadrangle. Placer gold claims are listed in table 2; only the claim on American Creek has any production history. Evidence is sparse for the accumulation of gold based on our studies of panned-concentrate samples (Church and Arbogast, 1989; Church and Bennett, 1989). Gold was seen in the panned-concentrate samples on Gas Creek (table 2, no. 21), in the Sugarloaf Mountain area near claim no. 22 (table 2), upstream from the American Creek claim (table 2, no. 23), and in a number of stream drainages in tract 1 (table 2, nos. 24 and 25). Gold was also found in panned concentrates in the drainages surrounding Mount Katolinat, in tracts $2 \mathrm{~A}$ and $2 \mathrm{~B}$, and in tracts $4 \mathrm{~A}$ and $4 \mathrm{C}$. These data indicate possible source areas for gold placer accumulations in coarse stream gravel where the tributaries abruptly change gradient as they enter the larger stream channels that drain these areas (mineral deposit model 39a; Yeend, 1986). Numerous stream channels fit these criteria. On the basis of our geochemical studies (Church and Arbogast, 1989), source areas for gold imply possible placer gold accumulations along the upper reaches of the Rainbow River and Ikagluik Creek in the central part of Katmai National Park and Preserve, in the larger stream channels in tract 1 in the Kulik Lake area (table 2, nos. 24 and 25), in the American Creek drainage (table 2, no. 23), in tract 4C along stream channels before entering the Big River drainage, in the high-energy part of the larger stream channels of tract $4 \mathrm{~A}$, and in the large streams in tract $4 \mathrm{~A}$ at tidewater (table 2, claims nos. 28-32). 
Scattered drainages underlain by the Naknek Formation (unit Jn, plate 4, Church and others, in press) also contain detectable gold in the nonmagnetic, heavy-mineral panned concentrates (Church and Arbogast, 1989; Church and Bennett, 1989). Studies of the magnetite-rich lenses in the Naknek Formation in the Ugashik-Karluk study area (Church, Detterman, and Wilson, 1989) indicated no placer gold accumulations might be expected to occur either in, or from the erosion of, these magnetite-rich lenses in the Ugashik-Karluk study area. As a result, no further sampling of the magnetite-rich lenses in the Naknek Formation was done during the Katmai study. Placer gold also might be found in the conglomeratic facies of the Naknek Formation, but our geochemical reconnaissance studies have not delineated areas favorable for the accumulation of gold placers in drainage basins underlain by rocks of the Naknek Formation (plate 4, Church and others, in press).

Berryhill (1963, p. 28-31) and Kimball (1972) investigated the shoreline placer magnetite accumulation on Egegik Beach (table 2, no. 19) as a possible resource for titanium (mineral deposit model 39c; Force, 1986). Lenses of black sand are usually less than $15 \mathrm{~cm}$ thick and cover an area of less than one acre. Samples from the two highest grade lenses average 23 percent magnetite, 11 percent ilmenite and a trace of flour gold in the small-size fraction (minus-65-mesh, $0.21 \mathrm{~mm}$; Kimball, 1972). The tonnage is small and ore grades from these occurrences are too low (table 2, no. 19) to be considered a titanium resource according to the grade-tonnage model (Attanasi and DeYoung, 1986). Berryhill (1963) concluded that these black sands constitute a mineral occurrence rather than a beach placer for gold and titanium-rich magnetite and ilmenite.

\section{Estimate of the number of undiscovered metallic mineral deposits}

The mineral deposit types we recognize or deem possibly present in the Katmai study area are summarized in table 4 . In order that the speculative nature of the mineral deposit data base be clearly understood, we have listed separately for each tract those mineral deposit types that we can clearly define on the basis of our field studies. Listed separately are those mineral deposit types that we suggest are present on the basis of our geochemical data or on the basis or poorly exposed or understood geologic relationships. For example, one undiscovered porphyry copper-molybdenum occurrence has been identified and characterized in tract $2 \mathrm{~A}$ (table 1, no. 3), but exploration data are insufficient to evaluate it for tonnage and grade. The geology and geochemistry at six additional sites are favorable for undiscovered porphyry copper deposits. Whether the grades and tonnages of any of these occurrences lie on the grade-tonnage curves for porphyry copper deposits (Singer and others, 1986) is unknown. Eleven polymetallic vein occurrences have been identified and their characteristics outlined (table 1), but not all of them are of sufficient tonnage to constitute polymetallic vein deposits according to Bliss and Cox (p. 127, 1986; the median size is about 8,400 tons). The list of occurrences given in table 1 reflects some minimum estimate, probably about five percent, of the number of undiscovered polymetallic veins present in the Katmai study area. This estimate would suggest that about 200 polymetallic veins are present within the Katmai study area. Of these, the grades and tonnages of only a small number of them would lie on the grade-tonnage curve for polymetallic vein deposits (Bliss and Cox, 1986).

Because of the reconnaissance nature of AMRAP studies and the paucity of mineral exploration activity in the Katmai study area, estimates of the number of undiscovered mineral deposits have been made for only a few mineral deposit types. Porphyry copper deposits usually have a large areal exposure and the probability of detecting them at the 1:250,000 scale at which our reconnaissance sampling has been done is high. We estimate that there is a ten percent probability of one or more undiscovered porphyry copper deposits in the Katmai study area. On the basis of our data, we estimate that there is a five percent probability of five or more undiscovered polymetallic vein deposits in the Katmai study area. We feel that our geologic and geochemical information, particularly in the absence of aeromagnetic data from that part of the study area east of the Naknek quadrangle, is too sparse to make quantitative estimates of the number of undiscovered mineral deposits for several mineral deposit types. This is the case for massive sulfide, porphyry molybdenum, and epithermal vein deposits. By indicating that tracts in the Katmai study area have potential for a mineral deposit type, we imply that the geologic and geochemical data are sufficiently encouraging that a mineral exploration company might prospect for such a mineral deposit in the area given adequate economic and environmental conditions, infrastructure, and land access. 


\section{NONMETALLIC RESOURCES}

Nonmetallic mineral resources include cinder (road ballast), pumice (lightweight aggregate or abrasive), and sand and gravel (construction and road ballast). Sand and gravel deposits are plentiful in the populated western part of the Katmai study area. They occur as surface exposures of fluvial deposits of modern and abandoned river channels as well as outwash from multiple cycles of glaciation. Sand and gravel deposits also are found locally on floors of larger valleys in the eastern part of the Katmai study area. Specific tracts for sand and gravel have not been delineated in this report; they can be readily inferred from a map of surficial deposits (Riehle and Detterman, in press).

Cinder is found at volcanoes that erupt lowsilica magma (basalt or basaltic andesite). Such volcanoes are uncommon in the study area; the few examples are small cinder cones at the south margin of the study area (T. 25 S., R. 42 W.) and on the north (T. 18 S., R. 31 W.) and south (T. 18 S., R. 32 W.) sides of the Savonoski River. Because of the remote nature of these sites from any market, their small size, and the absence of infrastructure, they do not constitute a resource for cinder.

Small pumice deposits are found near many of the Quaternary volcanoes in the Katmai study area, but those most amenable to development are the fallout deposits of the 1912 Katmai eruption. Roehm (unpub. data, 1947) and Moxham (1951) reported pumice accumulations in many of the bays along the eastern margin of the Katmai study area where pumice exceeds a depth of $1 \mathrm{~m}$ near tidewater (table 2, nos. 28-32). The primary thickness of pumice also exceeds $1 \mathrm{~m}$ along Shelikof Strait between Dakavak Bay and Kukak Bay (J. Fierstein, written commun., 1990); much thicker accumulations are found in areas where pumice has slumped from steep slopes along the Katmai River. Moxham (1951) and Eckhart and Plafker (1959) reported production of a small amount of pumice from Geographic Harbor in 1950-52 (table 2, no. 30). Restricted access and availability of alternative sources of high-silica, lightweight aggregate to local markets in Anchorage have both contributed to a lack of demand for pumice from the Katmai study area (Rutledge and others, 1953).

\section{ENERGY RESOURCES}

\section{Geothermal Resources}

Historic eruptions are known to have occurred at Trident and Novarupta volcanoes. Eruptions during the past 10,000 years have probably occurred at one or more of Martin, Mageik, Katmai, Griggs, Snowy, Kaguyak, and Douglas volcanoes in the study area. Such volcanic activity implies potential for geothermal resources. High-level magma chambers, which are indicated by large, silica-rich volcanic deposits and associated calderas, or both, are, however, lacking in the Katmai study area except for Novarupta dome. A few warm springs in the eastern part of the study area are briefly described by Riehle and Detterman (in press). We conclude that there is potential for low-temperature geothermal resources associated with circulation of meteoric water in the vicinity of the volcanoes at the crest of the Aleutian Range. We have not identified specific tracts for geothermal resources because of the paucity of site-specific data and the remoteness of the area from local markets. If geothermal resources were to be developed on the Alaska Peninsula, there are better areas where both the thermal regime and the land access appear more suitable (see Smith and Shaw, 1975).

\section{Petroleum Resources}

The petroleum potential of the Katmai study area is best evaluated from information available in adjacent areas, both onshore and offshore (fig. 3). The oil and gas potential south of the Katmai study area in the Ugashik, Bristol Bay, and western Karluk quadrangles (Church, Detterman, and Wilson, 1989) is divided into two areas, west (E1) and east (E2). We refer the reader to their description for the E1 area adjacent to the Bristol Bay. No new data are available from tract E1. Although the Tertiary sedimentary rocks contain type III kerogen that could produce thermogenic gas and some oil, the rocks have not been buried or otherwise sufficiently heated to form hydrocarbons. We concur with the conclusion of Church, Detterman, and Wilson (1989) that this province, onshore, does not have potential for thermogenic oil or gas. However, shallow accumulations of microbial gas are possible.

Tract E2, defined as the area generally east of the Bruin Bay fault (fig. 3), refers to the areas both to the north and south of the Katmai study area. In the Kenai quadrangle to the northeast in the Cook 
Inlet area, 1.2 billion barrels of oil and 8.6 trillion cubic feet of gas has been or will be produced from Tertiary reservoir rocks (Magoon and Kirschner, 1990). Eighty percent of the oil is from the Hemlock Conglomerate, 18 percent from the Tyonek Formation, and 2 percent is from the West Foreland Formation, which is equivalent in age to the Copper Lake Formation (Magoon, Adkinson, and Egbert, 1976). The shallower microbial gas is produced from the Beluga and Sterling Formations. As of December 1986, the estimated mean amount of undiscovered recoverable resources remaining in Cook Inlet is 61 million barrels of oil and 0.3 trillion cubic feet of gas (U.S. Geological Survey and Minerals Management Service, 1988). In the combined areas of the Iliamna and Seldovia quadrangles, oil seeps are found onshore in or near outcrops of Mesozoic rock on the west side of Cook Inlet; oil was recovered from Mesozoic and Tertiary rocks penetrated in wells onshore and offshore (Blasko, 1976; Magoon and Claypool, 1981; Magoon, 1986; Magoon and Anders, 1992). Just outside the Katmai study area along the south shore of Kamishak Bay (mouth of the Douglas River, Iliamna quadrangle), sandstone within the Naknek Formation is oil-stained (Magoon and others, 1979; Detterman and Reed, 1980; Magoon and Claypool, 1981). In the Ugashik and Karluk quadrangles just south of the Katmai study area, active oil seeps are known on the Ugashik anticline, in Oil Creek, and in nearby creeks between Puale Bay and Portage Bay (Blasko, 1976; Church, Detterman, and Wilson, 1989). These hydrocarbon indications adjacent to the Katmai study area suggest at least some oil and gas potential within tract E2.

In order to have a significant petroleum deposit, sufficient organic matter $(>1.0$ weight percent organic carbon) of the proper type (type I, type II, or type III) must be subjected to sufficient burial with attendant heat (vitrinite reflectance values $>0.6 \%$ Ro) before oil or gas can be generated and expelled from a source rock. After expulsion from the source rock, sufficient quantities of petroleum must migrate through a carrier bed to a reservoir rock that is sealed against further migration (that is, trapped). In addition, microbes metabolizing near-surface organic matter create natural gas deposits such as those found in the upper part of Cook Inlet (Claypool and others, 1980). The probability that all these ingredients occur in time and space to create a petroleum accumulation is quite low. Obviously, this has happened in the Kenai quadrangle as both oil and gas are being produced from Tertiary reservoir rocks. Adjacent to the Katmai study area, hydrocarbons have been generated and are migrating as indicated by active seeps. What is unknown is whether a commercial accumulation is present within or adjacent to the Katmai study area. Based on the most recent assessment, the likelihood of a commercial accumulation is quite low (U.S. Geological Survey and Minerals Management Service, 1988). In order to understand this assessment, the most likely cause of the oil seeps must be conveyed.

Surface exposures within the Katmai study area include rocks that range in age from Late Jurassic through early Tertiary. Certain units, such as the Naknek Formation and lower Tertiary rock units, contain coaly material (type III and type IV kerogen) which is gas prone. Except where coal is close to intrusive rocks along the coast, the rank of the coal is quite low indicating low probabilities for gas. All other rock units within the Katmai study area have average organic carbon contents (TOC) that are less than 1.0 weight percent indicating that they are poor source rocks for oil or gas. The thermal maturity of surface exposures increases substantially from a background level of $0.4 \%$ Ro (immature) in the Kamishak Hills to $4.0 \%$ Ro (overmature) in the sedimentary rocks adjacent to the Mount Douglas-Fourpeaked Mountain intrusions. Table 5 summarizes the available information on total organic carbon (TOC) available in the source rocks and their thermal maturity (\%Ro) in the Katmai study area.

Surface exposures and rock samples from outside the Katmai study area indicate that the Upper Triassic and Middle Jurassic rocks are oilprone source rocks (Magoon and Anders, 1992). Using carbon isotope data and biological marker information, oil from areas adjacent to the Katmai study area correlate with the Upper Triassic and Middle Jurassic rocks rich in organic matter; these two rock units are locally heated by intrusions that produce the oil stains and seeps.

Reservoir rocks are absent or provide poor traps within the Kenai area as evidenced by the dry wells drilled both in the lower Cook Inlet and on the Kenai Peninsula (fig. 3). Reservoir data from rocks within or adjacent to the Katmai study area are shown in table 6 (data from Magoon, Adkinson, Chmelik, and others, 1976, p. 50) and in Church, Detterman, and Wilson (table 6; 1989). Based on the porosity and permeability of these rock units, they are poor reservoirs. However, in the subsurface, reservoir properties may improve. The Naknek Formation and the sandstone of the Chinitna Formation and Tuxedni Group, if present in the 
subsurface, are better potential reservoir rocks within the Katmai study area. The Naknek Formation is exposed over much of the area. Where these reservoir rocks are buried, their depths are shallow enough that even if oil were encountered, the likelihood that it would have been flushed with meteoric water biodegrading the oil is very high. Near the coast, where the Naknek Formation is buried beneath Cretaceous and Tertiary rocks, it is intruded by igneous rocks and is overmature. Oil produced in the Kenai quadrangle to the north comes from lower Tertiary rocks, but in the Katmai region, these same rocks are exposed next to intrusive rocks along the coast and are thermally mature to overmature (table 5).

In summary, the possibility that some oil exists within area E2 in the Katmai study area in the subsurface is good, but there is little likelihood that it would be of commercial value.

\section{Coal Resources}

Coal in economic rank and volume is present in continental sedimentary rocks of Cretaceous age at the south end of the Alaska Peninsula as well as in Tertiary continental sedimentary rocks in Cook Inlet (Barnes, 1967; Merritt and McGee, 1986). Cretaceous rocks in the Katmai study area are of marine origin and have no coal seams, but upper Oligocene rocks near Amalik Bay contain thin coal seams. A shallow adit about $3 \mathrm{~m}$ above high tide 3 km northeast of Cape Ilktugitak (table 1, no. 17) may have been a coal prospect (U.S. Bureau of Mines Claim Files, Anchorage, 1990). Stone (1905, p. 161-162) reported the coal to be of a "bony" nature, suitable for a forge, and in beds about $45 \mathrm{~cm}$ thick. Similar coal seams were examined in inner Geographic Harbor (sec. 18, T. 24 S., R. 32 W.). Seams near Cape Ilktugitak are composed of 4 beds, each about $1 \mathrm{~m}$ in thickness, and the coal is fissile, glossy, and bituminous in appearance. These units could constitute a coal resource given different land accessibility and a local market.

\section{REFERENCES CITED}

Andreasen, G.E., Dempsey, W.J., Vargo, J.L., and others, 1963a, Aeromagnetic map of part of the Naknek quadrangle, Alaska: Geophysical Investigations Map GP-353, scale 1:125,000. $1963 \mathrm{~b}$, Aeromagnetic map of parts of the Ugashik and Karluk quadrangles, Alaska:
Geophysical Investigations Map GP-354, scale 1:125,000.

Attanasi, E.D., and DeYoung, J.H., 1986, Grade and tonnage model of shoreline placer $\mathrm{Ti}$, in $\mathrm{Cox}$, D.P., and Singer, D.A., eds., Mineral deposit models: U.S. Geological Survey Bulletin 1693, p. 270-273.

Atwood, W.W., 1911, Geology and mineral resources of parts of the Alaska Peninsula: U.S. Geological Survey Bulletin 467, 137 p.

Barnes, F.F., 1967, Coal resources of Alaska: U.S. Geological Survey Bulletin 1242-B, 36 p.

Beikman, H.M., 1980, Geologic map of Alaska: U.S. Geological Survey, scale 1:2,500,000.

Berg, H.C., and Cobb, E.H., 1967, Metalliferous lode deposits of Alaska: U.S. Geological Survey Bulletin 1246, 254 p.

Berryhill, R.V., 1963, Reconnaissance of beach sands, Bristol Bay, Alaska: U.S. Bureau of Mines, Report of Investigations 6214, 48 p.

Blasko, D.P., 1976, Oil and gas seeps in Alaska, Alaska Peninsula, western Gulf of Alaska: U.S. Bureau of Mines Report of Investigations 8122, $78 \mathrm{p}$.

Bliss, J.D., and Cox, D.P., 1986, Grade and tonnage model of polymetallic veins, in Cox, D.P., and Singer, D.A., eds., Mineral deposit models: U.S. Geological Survey Bulletin 1693, p. 125-129.

Calderwood, K.W., and Fackler, W.C., 1972 , Proposed stratigraphic nomenclature for Kenai Group, Cook Inlet Basin, Alaska: American Association of Petroleum Geologists Bulletin, v. 56, p. 739-754.

Case, J.E., Detterman, R.L., Wilson, F.H., Chuchel, B.A., and Yount, M.E., 1988, Maps showing aeromagnetic survey and geologic interpretation of the Ugashik and part of the Karluk quadrangles, Alaska: U.S. Geological Survey Miscellaneous Field Studies Map MF-1539-D, scale 1:250,000.

Church, S.E., and Arbogast, B.F., 1989, Geochemical map showing the distribution of selected elements determined in nonmagnetic heavy-mineral concentrates from the Mount Katmai and portions of the Afognak and Naknek quadrangles, Alaska: U.S. Geological Survey Miscellaneous Field Studies Map MF-2021-C, scale 1:250,000.

Church, S.E., Bailey, E.A., and Riehle, J.R., 1989, Geochemical map showing the distribution of selected elements determined in stream sediments from the Mount Katmai and portions of the Afognak and Naknek quadrangles, Alaska: 
U.S. Geological Survey Miscellaneous Field Studies Map MF-2021-A, scale 1:250,000.

Church, S.E., and Bennett, G.J., 1989, Mineralogical map showing the distribution of selected minerals identified in nonmagnetic heavymineral concentrates from the Mount Katmai and portions of the Afognak and Naknek quadrangles, Alaska: U.S. Geological Survey Miscellaneous Field Studies Map MF-2021-D, scale 1:250,000.

Church, S.E., Detterman, R.L., and Wilson, F.H., 1989, Mineral and Energy resource assessment maps of the Ugashik, Bristol Bay, and westem Karluk quadrangles, Alaska: U.S. Geological Survey Miscellaneous Field Studies Map MF-1539-I, scale 1:250,000.

Church S.E., Frisken, J.G., and Wilson, F.H., 1989, Interpretation of Exploration Geochemical Data from the Ugashik, Bristol Bay, and western Karluk quadrangles, Alaska: U.S. Geological Survey Bulletin 1858, 45 p.

Church, S.E., and Motooka, J.M., 1989, Geochemical maps showing the distribution of selected leachable metals determined by ICP in stream sediments from the Mount Katmai and portions of the Afognak and Naknek quadrangles, Alaska: U.S. Geological Survey Miscellaneous Field Studies Map MF-2021-B, scale 1:250,000.

Church, S.E., Riehle, J.R., and Goldfarb, R.J., in press, Interpretation of Exploration Geochemical Data from the Mount Katmai quadrangle and adjoining parts of the Afognak and Naknek quadrangles, Alaska: U.S. Geological Survey Bulletin 2020.

Claypool, G.E., Threlkeld, C.N., and Magoon, L.B., 1980, Biogenic and thermogenic origins of natural gas in Cook Inlet basin, Alaska: American Association of Petroleum Geologists Bulletin, v. 64, p. 1,131-1,139.

Cobb, E.H., 1972a, Metallic mineral resources map of the Mount Katmai quadrangle, Alaska: U.S. Geological Survey Miscellaneous Field Studies Map MF-461, scale 1:250,000.

1972b, Metallic mineral resources map of the Naknek quadrangle, Alaska: U.S. Geological Survey Miscellaneous Field Studies Map MF-442, scale 1:250,000.

1972c, Metallic mineral resources map of the Afognak quadrangle, Alaska: U.S. Geological Survey Miscellaneous Field Studies Map MF-470, scale 1:250,000. 1980 , Summaries of data on and lists of references to metallic and selected nonmetallic mineral deposits in fifteen quadrangles in southwestern and west-central Alaska: U.S. Geological Survey Open-File Report 80-909, 103 p.

Cox, D.P., 1986a, Descriptive model of porphyry $\mathrm{Cu}$, in Cox, D.P., and Singer, D.A., eds., Mineral deposit models: U.S. Geological Survey Bulletin 1693, p. 76. 1986b, Descriptive model of porphyry $\mathrm{Cu}-$ Mo, in Cox, D.P., and Singer, D.A., eds., Mineral deposit models: U.S. Geological Survey Bulletin 1693, p. 115.

1986c, Descriptive model of porphyry $\mathrm{Cu}-\mathrm{Au}$, in Cox, D.P., and Singer, D.A., eds., Mineral deposit models: U.S. Geological Survey Bulletin 1693, p. 110.

1986d, Descriptive model of polymetallic veins, in Cox, D.P., and Singer, D.A., eds., Mineral deposit models: U.S. Geological Survey Bulletin 1693, p. 125. 1986e, Descriptive model of Fe skarn deposits, in Cox, D.P., and Singer, D.A., eds., Mineral deposit models: U.S. Geological Survey Bulletin 1693, p. 94. 1986f, Descriptive model of $\mathrm{Zn}-\mathrm{Pb}$ skarn deposits, in Cox, D.P., and Singer, D.A., eds., Mineral deposit models: U.S. Geological Survey Bulletin 1693, p. 90.

Cox, D.P., Detra, D.E., and Detterman, R.L., 1981, Mineral resource maps of the Chignik and Sutwik Island quadrangles, Alaska: U.S. Geological Survey Miscellaneous Field Studies Map MF-1053-K, scale 1:250,000.

Cox, D.P., and Singer, D.A., editors, 1986, Mineral Deposit Models: U.S. Geological Survey Bulletin 1693, $379 \mathrm{p}$.

Csejtey, Bala, Jr., and Griscom, Andrew, 1978, Preliminary aeromagnetic interpretive map of the Talkeetna Mountains quadrangle, Alaska: U.S. Geological Survey Open-File Report 78-558-C, 14 p., 2 sheets, scale 1:250,000.

Danielson, Vivian, 1991, Cominco discovers large copper-gold porphyry in Alaska: Northern Miner, v. 76, no. 47, p. 1 and 19.

Detterman, R.L., Case, J.E., and Wilson, F.L., 1979, Paleozoic rocks on the Alaska Peninsula, in Johnson, K.M., and Williams, J.R., eds., Alaska accomplishments during 1978: U.S. Geological Survey Circular 804-B, p. 85-86.

Detterman, R.L., Case, J.E., Wilson, F.L., and Yount, M.E., 1987, Geologic map of the Ugashik, Bristol Bay, and part of the Karluk quadrangles, Alaska: U.S. Geological Survey 
Miscellaneous Investigations Series Map I-1685, scale $1: 250,000$.

Detterman, R.L., and Hartsock, J.K., 1966, Geology of the Iniskin-Tuxedni region, Alaska: U.S. Geological Survey Professional Paper 512, 78 p.

Detterman, R.L., Hudson, Travis, Plafker, George, Tysdal, R.G., and Hoare, J.M., 1976, Reconnaissance geologic map along the Bruin Bay and Lake Clark faults in the Kenai and Tyonek quadrangles, Alaska: U.S. Geological Survey Open-File Report 76-477, 2 pl., scale $1: 250,000$.

Detterman, R.L., Miller, J.W., Case, J.E., Wilson, F.H., and Yount, M.E., in press, Stratigraphic framework of the Alaska Peninsula: U.S. Geological Survey Bulletin 1969-A.

Detterman, R.L., and Reed, B.L., 1980, Stratigraphy, structure, and economic geology of the Iliamna quadrangle, Alaska: U.S. Geological Survey Bulletin 1368-B, $86 \mathrm{p}$.

Eckhart, R.A., and Plafker, George, 1959, Haydite raw material in the Kings River, Sutton, and Lawing Areas, Alaska: U.S. Geological Survey Bulletin 1039-C, p. 33-34.

Egbert, R.M., and Magoon, L.B., 1981, Petrography, provenance, and tectonic significance of Middle and Upper Jurassic sandstone from Tuxedni Bay, Cook Inlet, Alaska, in Albert, N.R.D., and Hudson, T., eds., The United States Geological Survey in Alaska--Accomplishments during 1979: U.S. Geological Survey Circular 823-B, p. 86-88.

Fisher, M.A., 1981, Location of the Border Ranges fault southwest of Kodiak Island: Geological Society of America Bulletin, v. 92, p. 19-30.

Fisher, M.A., Bruns, T.R., and von Huene, Roland, 1981, Transverse tectonic boundaries near Kodiak Island, Alaska: Geological Society of America Bulletin, v. 92, p. 10-18.

Force, E.R., 1986, Descriptive model of shoreline placer Ti, in Cox, D.P., and Singer, D.A., eds., Mineral deposit models: U.S. Geological Survey Bulletin 1693, p. 270.

Frisken, J.G., Church, S.E., Detra, D.E., and Willson, W.R., 1988, Geochemical map showing the distribution of selected elements determined in nonmagnetic heavy-mineral concentrates from the Ugashik, Bristol Bay, and western Karluk quadrangles, Alaska: U.S. Geological Survey Miscellaneous Field Studies Map MF-1539-G, scale 1:250,000.

Frisken, J.G., Church, S.E., and Willson, W.R., 1988, Mineralogical map showing the distribution of selected ore-related minerals identified in the nonmagnetic heavy-mineral concentrates from the Ugashik, Bristol Bay, and western Karluk quadrangles, Alaska: U.S. Geological Survey Miscellaneous Field Studies Map MF-1539-H, scale 1:250,000.

Green, C.B., Bundtzen, T.K., Peterson, R.J., Seward, A.F., Deagen, J.R., and Butron, J.E., 1989, Alaska's Mineral Industry, 1988: Alaska Division of Geological and Geophysical Surveys Special Report 43, 79 p.

Hanson, B.M., 1957, Middle Permian limestone on the Pacific side of Alaska Peninsula: American Association of Petroleum Geologists Bulletin, v. 41, p. 2,376-2,378.

Heald, Pamela, Foley, N.K., and Hayba, D.O., 1987, Comparative anatomy of volcanic-hosted epithermal deposits--acid-sulfate and adulariasericite types: Economic Geology, v. 82, p. 1-26.

Hollister, V.F., 1978, Geology of the Porphyry Copper Deposits of the Western Hemisphere: American Institute of Mining Engineers, New York, p. 55-88.

Kimball, A.L., 1972, Reconnaissance of Ugashik beach sands, Bristol Bay, Alaska: U.S. Bureau of Mines Open-File Report 21-72, 28 p.

Lanphere, M.A., and Reed, B.L., 1985, The McKinley sequence of granitic rocks--a key element in the accretionary history of southern Alaska: Journal of Geophysical Research, v. 90, p. 11,413-11,430.

MacKevett, E.M., Jr., and Holloway, C.D., 1977, Map showing metalliferous mineral deposits in the western part of southern Alaska: U.S. Geological Survey Open-File Report 77-169-F, 39 p.

Magoon, L.B., ed., 1986, Geologic studies of the lower Cook Inlet COST No. 1 well, Alaska Outer Continental Shelf: U.S. Geological Survey Bulletin 1596, 99 p.

Magoon, L.B., Adkinson, W.L., Chmelik, F.B., Dolton, G.L., Fisher, M.A., Hampton, M.A., Sable, E.G., and Smith, R.A., 1976, Hydrocarbon potential, geologic hazards, and infrastructure for exploration and development of the lower Cook Inlet, Alaska: U.S. Geological Survey Open-File Report 76-449, 124 p.

Magoon, L.B., Adkinson, W.L., and Egbert, R.M., 1976, Map showing the geology, wildcat wells, Tertiary plant fossil localities, $\mathrm{K}$-Ar age dates, and petroleum operations, Cook Inlet area, Alaska: U.S. Geological Survey Miscellaneous Investigations Series Map I-1019, 3 sheets, $1: 250,000$ scale. 
Magoon, L.B., and Anders, D.E., 1992, Oil-tosource-rock correlation using carbon-isotope data and biological marker compounds, Cook InletAlaska Peninsula, Alaska, in Moldowan, J.M., Albrecht, P., and Philps, R.P., eds., Biological markers in sediments and petroleum:

Hertfordshire, England, Prentice-Hall, p. 241279.

Magoon, L.B., Bouma, A.H., Fisher, M.A., Hampton, M.A., Scott, E.W., and Wilson, C.L., 1979, Resource report for proposed OCS sale no. 60, lower Cook Inlet-Shelikof Strait, Alaska: U.S. Geological Survey Open-File Report 79$600,38 \mathrm{p}$.

Magoon, L.B., and Claypool, G.E., 1981, Petroleum geology of Cook Inlet basin, Alaska--An exploration model: American Association of Petroleum Geologists Bulletin, v. 65, p. 1,0431,061 .

Magoon, L.B., and Egbert, R.M., 1986, Framework geology and sandstone composition, in Magoon, L.B., ed., Geologic studies of the lower Cook Inlet COST No. 1 well, Alaska outer continental shelf: U.S. Geological Survey Bulletin 1596, p. 65-90.

Magoon, L.B., and Kirschner, C.E., 1990, Alaska onshore National assessment program--Geology and petroleum resource potential of six onshore Alaska provinces: U.S. Geological Survey OpenFile Report 88-450-T, 47 p.

Marlow, M.S., Scholl, D.W., Buffington, E.C., and Alpha, T.R., 1973, Tectonic history of the central Aleutian arc: Geological Society of America Bulletin, v. 84, p. 1,555-1,574.

Martin, G.C., 1920, The Alaskan mining industry in 1918: U.S. Geological Survey Bulletin 712, p. 11-52.

Martin, G.C., and Katz, F.J., 1912, A geologic reconnaissance of the Iliamna region, Alaska: U.S. Geological Survey Bulletin 485, 138 p.

Mather, K.F., 1925, Mineral resources of the Kamishak Bay region, in Mineral Resources of Alaska, Report on progress of investigations in 1923: U.S. Geological Survey Bulletin 773, p. 159-181.

Merritt, R.D., and McGee, D.L., 1986, Depositional environments and resource potential of Cretaceous coal-bearing strata at Chignik and Herendeen Bay, Alaska Peninsula: Sedimentary Geology, v. 49, p. 21-49.

Mertie, J.B., Jr., 1938, The Nushagak district, Alaska: U.S. Geological Survey Bulletin 903, p. 96.
Mosier, D.L., Sato, Takeo, Page, N.J., Singer, D.A., and Berger, B.R., 1986, Descriptive model of Creede epithermal veins, in Cox, D.P., and Singer, D.A., eds., Mineral deposit models: U.S. Geological Survey Bulletin 1693, p. 145.

Moxham, R.M., 1951, Pumice deposits in the Alaska Peninsula-Cook Inlet region, Alaska: U.S. Geological Survey Open-File Report, 25 p.

Nelson, W.H., King, H.D., Case, J.E., Tripp, R.B., Crim, W.D., and Cooley, E.F., 1985, Mineral resource map of the Lake Clark quadrangle, Alaska: U.S. Geological Survey Miscellaneous Field Studies Map MF-1114-B, scale 1:250,000.

Newberry, R.J., 1986, Mineral Resources of the north central Chugach Mountains, Alaska: Alaska Division of Geological and Geophysical Surveys Report of Investigations 86-23, 44 p.

Page, N.J., 1986, Descriptive model of Bushveld FeTi-V, in Cox, D.P., and Singer, D.A., eds., Mineral deposit models: U.S. Geological Survey Bulletin 1693, p. 15.

Petering, G.W., and Smith, T.N., 1981, Stratigraphic sections, Hallo Bay to Katmai Bay, Shelikof Strait, Alaska, 1979: U.S. Geological Survey Open-File Report 81-21.

Reed, B.L., and Detterman, R.L., 1965, A preliminary report on some magnetite-bearing rocks near Frying Pan Lake, Iliamna D-7 quadrangle, Alaska: U.S. Geological Survey Open-File Report 817, 2 p.

Reed, B.L., and Lanphere, M.A., 1969, Age and chemistry of Mesozoic and Tertiary plutonic rocks in south-central Alaska: Geological Society of America Bulletin, v. 80, p. 23-44.

1973, Alaska-Aleutian Range batholithGeochronology, chemistry, and relation to circum-Pacific plutonism: Geological Society of America Bulletin, v. 84, p. 2,583-2,610.

Reed, B.L., Miesch, A.L., and Lanphere, M.A., 1983, Plutonic rocks of Jurassic age in the Alaska-Aleutian Range batholith-chemical variations and polarity: Geological Society of America Bulletin, v. 94, p. 1,232-1,240.

Riehle, J.R., Bailey, E.A., Church, S.E., and Yount, M.E., 1989, Sample locality maps, analytical data, and statistical summary of analyses of rock samples from the Mount Katmai quadrangle and adjacent portions of the Naknek and Afognak quadrangles, Alaska: U.S. Geological Survey Open-File Report 89-570, 136 p., scale $1: 250,000$.

Riehle, J.R., and Detterman, R.L., in press, Quaternary geologic map of the Mount Katmai quadrangle and adjacent parts of the Naknek and 
Afognak quadrangles, Alaska: U.S. Geological Survey Miscellaneous Investigations Series Map I-2032, scale 1:250,000.

Riehle, J.R., Detterman, R.L., Yount, M.E., and Miller, J.W., in press, Geologic map of the Mount Katmai quadrangle and adjacent parts of the Naknek and Afognak quadrangles, Alaska: U.S. Geological Survey Miscellaneous Investigations Map Series I-2204, scale $1: 250,000$.

Rutledge, F.A., Thorne, R.L., Kerns, W.H., and Mulligan, J.J., 1953, Nonmetallic deposits accessible to the Alaska railroad as possible sources of raw materials for the construction industry: U.S. Bureau of Mines Report of Investigations 4932, $129 \mathrm{p}$.

Scholl, D.W., Buffington, E.C., and Marlow, M.S., 1975 , Plate tectonics and the structural evolution of the Aleutian-Bering Sea region, in Forbes, R.B., ed., Contributions to the geology of the Bering Sea basin and adjacent regions: Geological Society of America Special Paper 151, p. 1-31.

Singer, D.A., 1986, Descriptive model of Kuroko massive sulfide, in Cox, D.P., and Singer, D.A., eds., Mineral deposit models: U.S. Geological Survey Bulletin 1693, p. 189.

Singer, D.A., Mosier, D.L., and Cox, D.P., 1986, Grade and tonnage model of porphyry $\mathrm{Cu}$, in Cox, D.P., and Singer, D.A., eds., Mineral deposit models: U.S. Geological Survey Bulletin 1693 , p. 77-81.

Shew, Nora, and Lanphere, M.A., in press, Map and table showing $\mathrm{K}$-Ar ages from the Mount Katmai, and adjacent parts of Naknek and Afognak quadrangles, Alaska: U.S. Geological Survey Miscellaneous Field Studies Map MF2021-E, scale 1:250,000.

Smith, R.L., and Shaw, H.R., 1975, Igneous related geothermal systems, in White, D.E., and Williams, D.L., eds., Assessment of geothermal resources of the United States: U.S. Geological Survey Circular 726, p. 58-83.

Smith, W.R., 1925, The Cold Bay-Katmai district [Alaska]: U.S. Geological Survey Bulletin 773, p. 183-207.

Steefel, C.I., 1987, The Johnson River prospect, Alaska: gold-rich sea-floor mineralization from the Jurassic: Economic Geology, v. 82, p. 894-914.

Stone, R.W., 1905, Coal resources of southwestern Alaska: U.S. Geological Survey Bulletin 259, p. 151-171.
Theodore, T.G., 1986, Descriptive model of porphyry Mo, low-F, in Cox, D.P., and Singer, D.A., eds., Mineral Deposit Models: U.S. Geological Survey Bulletin 1693, p. 120.

U.S. Bureau of Land Management, 1987, Alaska Land Status Map, June, 1987: scale 1:2,500,000.

U.S. Bureau of Mines, 1973, Alaska, 1/250,000 scale quadrangle map overlays showing mineral deposit locations, principal minerals, and number and type of claims: U.S. Bureau of Mines OpenFile Report 20-73.

U.S. Geological Survey and Minerals Management Service, 1988, National assessment of undiscovered conventional oil and gas resources-Working papers--National assessment of undiscovered conventional oil and gas resources: U.S. Geological Survey Open-File Report 88573, revised July $1989,511 \mathrm{p}$.

Wallace, W.K., and Engebretsen, D.C., 1984, Relationships between plate motions and Late Cretaceous to Paleogene magmatism in southwestern Alaska: Tectonics, v. 3, p. 295-315.

Wahraftig, Clyde, 1965, Physiographic divisions of Alaska: U.S. Geological Survey Professional Paper 482, $52 \mathrm{p}$.

Warfield, R.S., and Rutledge, F.A., 1951, Investigations of Kasna Creek copper prospect, Lake Kontrashibuna, Lake Clark region, Alaska: U.S. Bureau of Mines Report of Investigations $4828,10 \mathrm{p}$.

White, W.H., and Queen, L.D., 1989, Preliminary geologic and rock-chip geochemical data from drill core and trenches at the Shumagin gold deposit, Unga Island, Alaska: U.S. Geological Survey Open-File Report 89-361, 36 p.

Wilson, F.H., 1981, Map and table showing radiometric ages of rocks in the Aleutian Islands and the Alaska Peninsula: U.S. Geological Survey Open-File Report 81-471, 24 p., scale 1:1,000,000.

Wilson, F.H., 1985, The Meshik arc--an Eocene to earliest Miocene magmatic arc on the Alaska Peninsula: Alaska Division of Geological and Geophysical Surveys Professional Report 88, 14 p.

Wilson, F.H., White, W.H., DuBois, G.D., 1988, Brief descriptions of mines, prospects, and occurrences in the Port Moller and Stepovak Bay quadrangles, Alaska Peninsula: U.S. Geological Survey Open-File Report 88-666, 128 p.

Yeend, W.E., 1986, Descriptive model of placer AuPGE, in Cox, D.P., and Singer, D.A., eds., Mineral deposit models: U.S. Geological Survey Bulletin 1693, p. 261. 